\title{
Further Investigations on Rhizocarpon of North-Eastern Iran: R. geographicum
}

\author{
Mahroo Haji Moniri \\ Department of Biology, Faculty of Sciences, Islamic Azad University, Mashhad Branch, Mashhad 91756 89 119, Iran \\ Correspondence should be addressed to Mahroo Haji Moniri; h_moniri@yahoo.com
}

Received 15 January 2014; Accepted 7 April 2014; Published 29 April 2014

Academic Editor: Simona Nardoni

Copyright (c) 2014 Mahroo Haji Moniri. This is an open access article distributed under the Creative Commons Attribution License, which permits unrestricted use, distribution, and reproduction in any medium, provided the original work is properly cited.

Morphology, anatomy, secondary chemistry, ecology, and distribution of Rhizocarpon geographicum (Rhizocarpaceae, lichenized Ascomycota) in north-eastern Iran are investigated and discussed.

\section{Introduction}

Iran has an exceptional variety of biomes which has resulted in an extensive diversity in many organism groups including lichens. The history of lichenological exploration in northeastern Iran is fairly extensive, dating back to the middle of the twentieth century $[1,2]$. Since 2004, however, the investigations in the present Khorasan provinces have much increased due to the development of local expertise. The total number of the species reported from the region represents the crustose growth form as the dominant lichens [3-7]. Among the genera is the well-known and conspicuous yellowgreen group of Rhizocarpon which is abundant in ArcticAlpine environments worldwide. It grows very slowly $(0.02-$ $2 \mathrm{~mm} \mathrm{yr}^{-1}$ ) and lives to a considerable age [8]. The present paper is part of a series of studies intended as contributions towards a detailed treatment of Iran's lichen biota.

\section{Materials and Methods}

Field investigations were made by a party of two people during May-November 2006 and July 2007 with some more collecting in 2011. A total of 15 sampling sites were visited, situated in Razavi Khorasan province (127432 sq.km), which lies between $33^{\circ} 52^{\prime}-38^{\circ} 17^{\prime} \mathrm{N}$ latitudes and $55^{\circ} 17^{\prime}-61^{\circ} 15^{\prime} \mathrm{E}$ longitudes in north-eastern Iran (Figure 1). The study area belongs to the Irano-Turanian phytogeographical region [9]. Calcareous bed rock is predominant in the study area [10] and the elevation of the sites ranges from 1340 to $1880 \mathrm{~m}$. Over 537 Rhizocarpon thalli were investigated of which 311 (58\%) belong to R. geographicum. As a result much new information became available on the species of Rhizocarpon [11-13]. Morphological and anatomical characteristics of the thalli and fruiting bodies were examined with a stereomicroscope and a light microscope. Preparations were made in distilled water, $10 \% \mathrm{KOH}$ and $\mathrm{KI}$. The usual color tests were done by applying the reagents on the thallus or on exposed medulla [14]. The areoles of the thallus were separated under stereomicroscope and were extracted in acetone. Then the extractions were studied using two standard solvents, GAW and GE, on the basis of recrystallization of the soluble compounds [15]. Three specimens were subjected to thin-layer chromatography by M. Kukwa (Gdansk, Poland), S. R. Clayden (New Brunswick Museum, Canada), and the author by using solvent $\mathrm{C}$. The description below is based on these observations. Vouchers are stored in the private collection of the author.

\section{Results}

\subsection{Rhizocarpon geographicum (L.) DC.}

3.1.1. Description. The description: thallus spreading to $8 \mathrm{~cm}$ diameter, yellow-green to light yellow, composed of nearly compacted areoles; black prothallus distinct at the thallus margin and more or less between the areoles; areoles 0.2$1.4 \mathrm{~mm}$ in diameter, with less than one up to 4 areoles in 


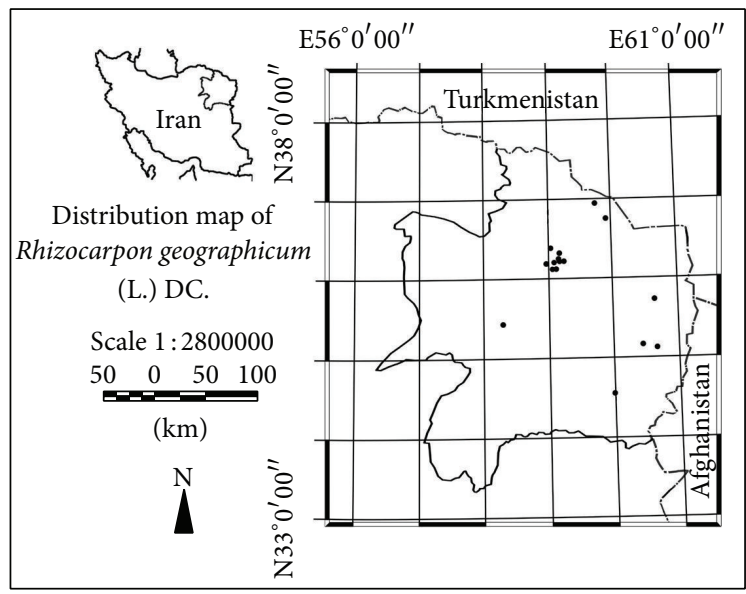

- Collection area

- Province boundary

-.- International boundary

FIGURE 1: Distribution of Rhizocarpon geographicum in Razavi Khorasan province, based on collected materials.

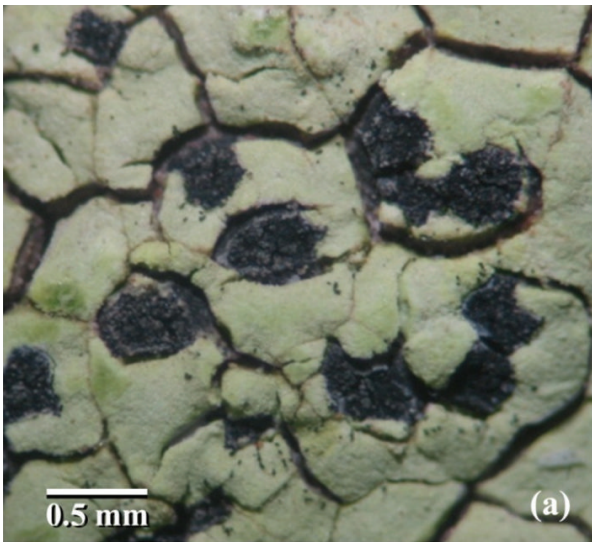

(a)

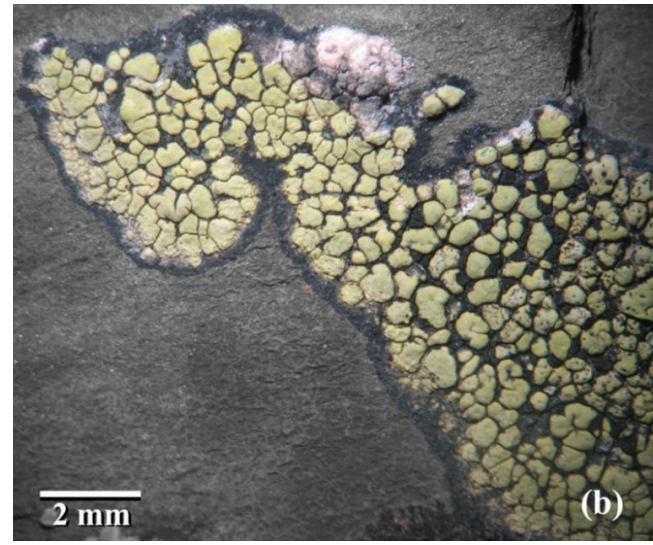

(b)

FIGURE 2: (a) The position of the apothecium. (b) General habitat and margin of Rhizocarpon geographicum.

one $\mathrm{mm}^{2}$, plane to strongly convex, surface not pruinose, shiny, with incomplete secondary fissuring of areoles (Figures 2(a)-2(b)), section of thallus in optical view $\mathrm{K}-, \mathrm{C}-$, or rarely $\mathrm{C}+\mathrm{red}$; secondary areoles angular, $0.2-0.4 \mathrm{~mm}$ in diameter, cortex pellucid, ca. $12-25 \mu \mathrm{m}$ thick; necrotic layer very thin; medulla white, $80-150 \mu \mathrm{m}$ thick, I + violet; algal layer continuous, $25-50 \mu \mathrm{m}$ thick, photobiont cells rounded, (3-)5-8(-12) $\mu \mathrm{m}$ diameter; hypothallus distinct, brown, 20$60 \mu \mathrm{m}$ thick (Figure 3); not sorediate; pycnidia not observed.

Apothecia mostly single, rarely 2-3 grouped together, (0.3-)0.5-1.0(-1.2) mm diam., black, angular to roundish, usually plane or slightly convex, more or less pruinose, with raised margin when young, usually surrounded by areoles (Figure 2(a)), with 30-80 $\mu \mathrm{m}$ thick brownish proper excipulum. Subhymenium usually 30-100 $\mu \mathrm{m}$ thick, dark brown. Hymenium $100-180 \mu \mathrm{m}$ tall, colourless to light green; hamathecial filaments anastomosing, hyaline, apically swollen. Epihymenium 15-30 $\mu \mathrm{m}$ thick, greenish brown or reddish brown, usually $\mathrm{K}-$, seldom $\mathrm{K}+$ reddish; without black granules (Figure 4). Spores: 8/ascus, submuriform to muriform, ellipsoid, occasionally with constricted ends, greenish brown, 20-36 × 10-20 $\mu \mathrm{m}$, with 15-27 locules (Figure 5).

3.1.2. Lichen Chemistry. Rhizocarpic acid and psoromic acid were identified by TLC. Calcium oxalate was detected by microcrystal test and identified by its needle-shaped crystals.

3.1.3. Distribution and Ecology. Rhizocarpon geographicum was found to be widespread in Razavi Khorasan $[5,6]$, except in the west, where it has only been found at one locality. It is mainly distributed at middle elevation (Figure 1) and its altitude ranges from $1340 \mathrm{~m}$ to ca. $1870 \mathrm{~m}$. 

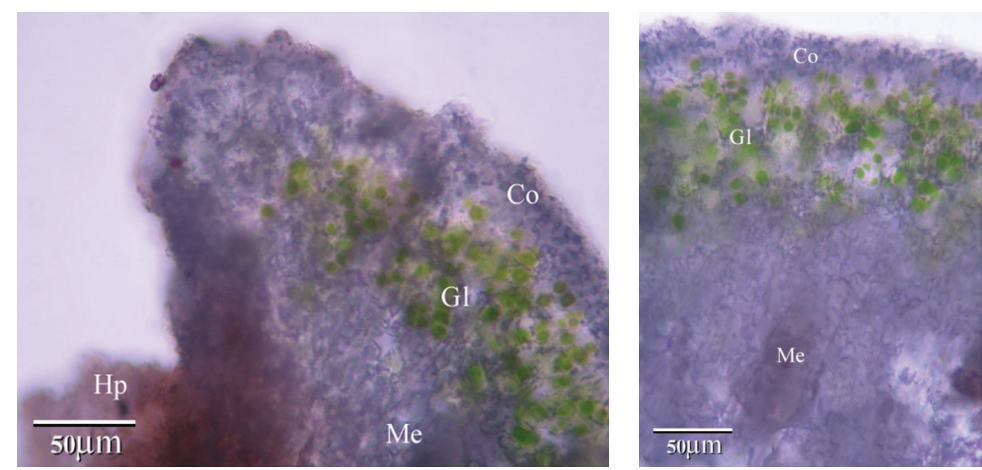

FIGURE 3: Transverse sections of secondary areoles with detailed views of layered structure; Co: cortex, Gl: gonidial layer, Me: medulla.

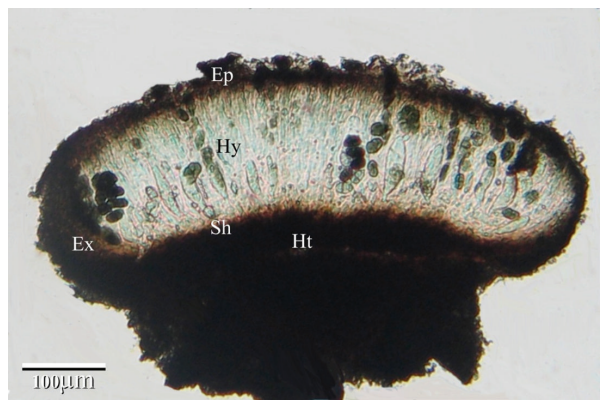

FIgURE 4: Apothecium section; Ep: epithecium, Hy: hymenium, Ex: exipulum, Sh: subhymenium, Ht: hamathecium.

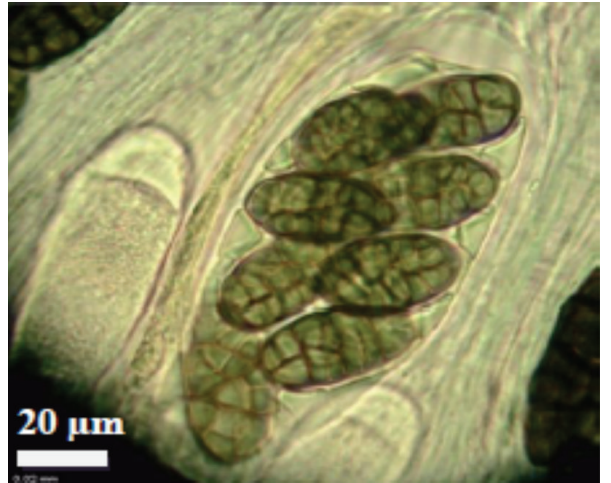

(a)

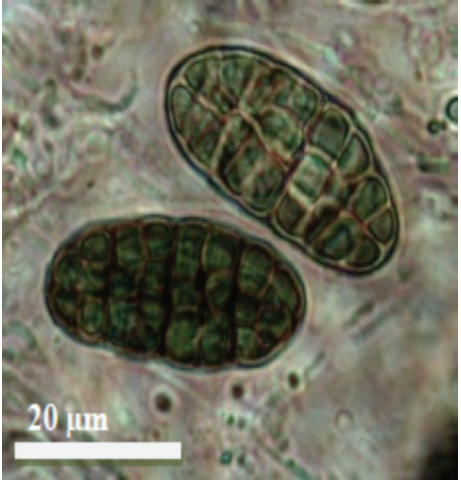

(b)

Figure 5: (a) Asci with ascospores in K. (b) Mature ascospores.

\section{Discussion}

In the $R$. geographicum-group the species $R$. geographicum is the most widespread and known to be a common species in all high mountains of the temperate regions [16]. This is in accordance with the observations in Iran, where it appeared to be common in most investigated areas of the province, while in the same area two further species of the geographicum-group, $R$. macrosporum and $R$. geographicum subsp. tinei, are represented by only three thalli $[5,6,11,13]$.

$R$. geographicum is found on exposed siliceous rock faces, closely associated with Acarospora impressula (Figure 6). Rarely, it has also been found on vertical and shaded rock faces. In its habitats R. geographicum is often the dominant species and often accompanied by thalli of the macrolichen Rhizoplaca melanophthalma and the crustose lichens $A$. impressula, Aspicilia calcarea, R. geminatum, A. bullata, Caloplaca variabilis, Candelariella vitellina, and Dimelanea oreina and two foliose lichens, Xanthoria elegans and Lecanoramuralis, while bryophytes are typically absent. This community is very common and widespread in upland Razavi Khorasan, above $1600 \mathrm{~m}$. The associated species of $R$. geographicum are graphically presented in Figure 6 . Where cyanolichens are dominant, $R$. geographicum is usually absent or of very low cover $[6,7]$. 


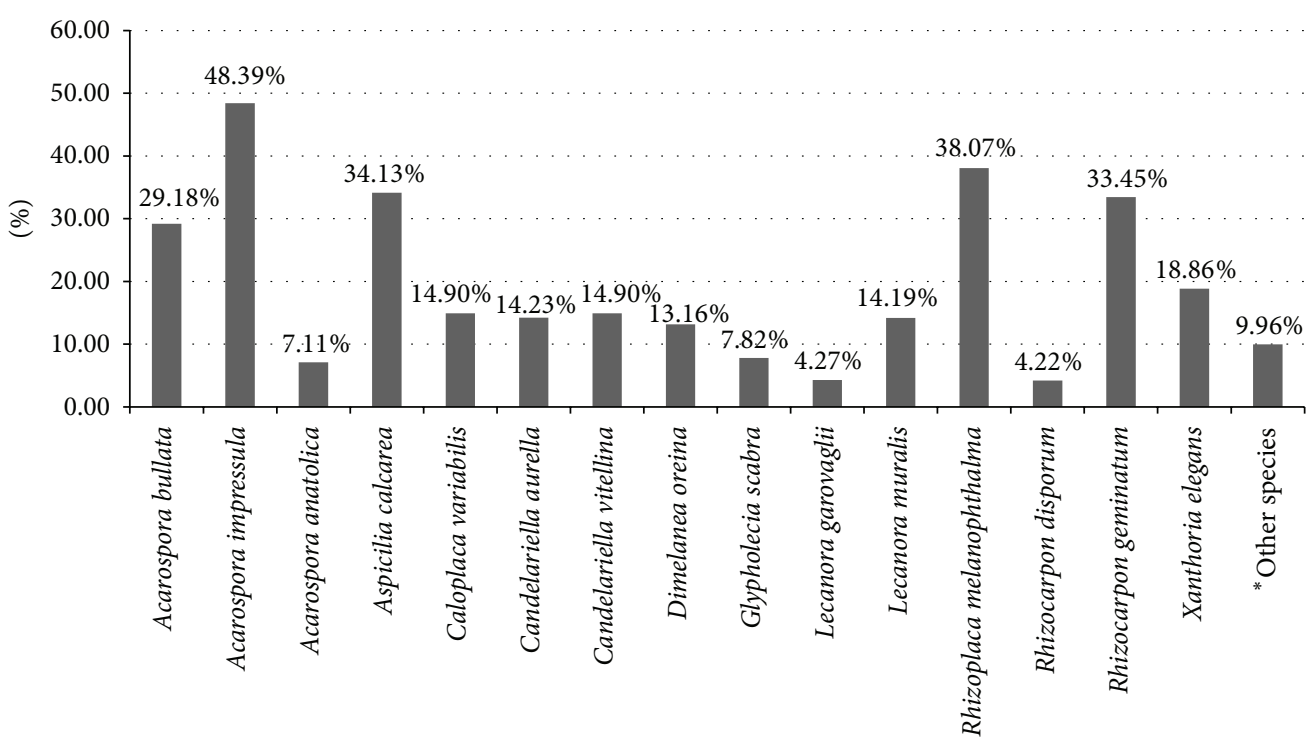

FIGURE 6: Graphic summary of redundancy analyses of adjacent species to R. geographicum (*: observed species less than 10 times).

Our observations on morphology agree with those of other investigators. R. geographicum comprises discrete areolae on a black hypothallus that extends beyond the areolae to form a marginal ring 2-3 $\mathrm{mm}$ in width [17]. It is representative of the geographicum-group, which is separated from other yellow-green taxa of Rhizocarpon by an indistinct epihymenium, a positive reaction of the medulla to iodine, and by pluriseptate ascospores. Within this group it is distinct by the combination of epruinose apothecia, esorediate and not parasitic thallus, and ascospore size. The septation allows an arrangement in four groups ranging from a few transverse septa to numerous septa in muriform ascospores [16].

The geographicum-group can be divided by three character complexes: colour and shape of the areoles, the development of the margin of apothecium, and the size and septation of the ascospores. These allow the differentiation between $R$. geographicum and $R$. lecanorinum, $R$. macrosporum and R.geographicum subsp. tinei, all of which have been recorded from Iran $[2,11]$. While these taxa are all yellow-green, there exist subtle differences in their thalli colours: areoles of $R$. geographicum look more greenish. The second trait concerns the absence of a pseudolecanorine margin of the apothecium of R. geographicum that makes it differ from R. lecanorinum. As to ascospore size, $R$. geographicum subsp. tinei (nearly $5 \mu \mathrm{m})[11]$ and $R$. macrosporum $(25-30 \mu \mathrm{m})$ [12] have larger ascospores than R. geographicum.

\section{Conclusions}

The data does not suggest any relationship between distributions of R. geographicum and humidity [17]. About half of the occurrences of $R$. geographicum were from very dry localities.

The reaction, $\mathrm{C}+$ red, is due to gyrophoric acid, but this could not be confirmed by TLC. Therefore, the two thalli showing $\mathrm{C}+$ red were probably contaminated by fragments of $R$. viridiatrum [12].
As R. geographicum is the dominant species among the known taxa of the genus in NE Iran $[6,11]$, it may be recommended for lichenometric investigations in the region.

\section{Conflict of Interests}

The author declares that there is no conflict of interests regarding the publication of this paper.

\section{Acknowledgments}

The author would like to acknowledge S. Kamyabi for making his Rhizocarpon collection available to her. Special thanks are due to Dr. Harrie Sipman for reviewing the paper. This work was funded by the research assistance service of the Islamic Azad University, Mashhad Branch.

\section{References}

[1] S. Szatala, "Lichenes," in Ergebnisse einer botanischen Reise nach dem. Iran, 1937, K. H. Rechinger, J. Baumgartner, F. Petrak, and S. Szatala, Eds., vol. 50 of Annales des Naturhistorischen Museums in Wien, pp. 521-533, 1940.

[2] S. Szatala, "Prodromus einer Flechtenflora des Irans," Annales Historico-Naturalis Musei Nationalis Hungarici, vol. 8, pp. 101154, 1957.

[3] M. R. D. Seaward, H. J. M. Sipman, M. Schultz, A. A. Maassoumi, M. Haji Moniri, and M. Sohrabi, "A preliminary lichen checklist for Iran,” Willdenowia, vol. 34, pp. 543-576, 2004.

[4] M. R. D. Seaward, H. J. M. Sipman, and M. Sohrabi, "A revised checklist of lichenized, lichenicolous and allied fungi for Iran," Sauteria, vol. 15, pp. 459-520, 2008.

[5] M. Hadjmoniry, F. Fallahian, and A. A. Maassoumi, "Lichens from the Khorasan Province, Iran," Folia Cryptogamica Estonica, vol. 41, pp. 55-57, 2005.

[6] M. Haji Moniri and H. J. M. Sipman, "Lichens from two nature reserves in NE Iran,” Willdenowia, vol. 39, pp. 199-202, 2009. 
[7] M. H. Moniri and H. J. M. Sipman, "Lichens from three mountain sites in Khorasan provinces, Iran, including four species new to Iran," Cryptogamie, Mycologie, vol. 32, no. 2, pp. 145-150, 2011.

[8] R. A. Armstrong and S. N. Smith, "Development and growth of the lichen Rhizocarpon geographicum," Symbiosis, vol. 3, pp. 287-300, 1987.

[9] A. Takhtajan, Floristic Regions of the World, University of California Press, Berkeley, Calif, USA, 1986.

[10] A. Aghanabati, Geology of Iran, Tehran University Press, 2004.

[11] M. H. Moniri, S. Kamyabi, and A. M. Fryday, "Rhizocarpon saurinum new to Asia, and other reports of Rhizocarpon species from Razavi Khorasan Province, Iran," Mycologia Balcanica, vol. 6, pp. 89-92, 2009.

[12] M. Haji Moniri and S. Kamyabi, "On Rhizocarpon viridiatrum (Wulfen) Körb. in north-eastern Iran," The Iranian Journal of Botany, vol. 17, no. 2, pp. 276-281, 2011.

[13] M. Haji Moniri, S. Kamyabi, and S. R. Clayden, "A preliminary study of Rhizocarpon macrosporum in Razavi Khorasan province (NE Iran)," The Iranian Journal of Botany, vol. 16, no. 1, pp. 185-189, 2010.

[14] A. Orange, P. W. James, and F. J. White, Microchemical Methods for the Identification of Lichens, British Lichen Society, London, UK, 2001.

[15] S. Huneck and I. Yoshimura, Identification of Lichen Substances, Springer, Berlin, Germany, 1977.

[16] H. Runemark, "Studies in Rhizocarpon, 1. Taxonomy of the yellow species in Europe," Opera Botanica, vol. 2, pp. 1-152, 1956.

[17] R. A. Armstrong and T. Bradwell, "Variation in hypothallus width and the growth of the lichen Rhizocarpon geographicum (L.) DC," Symbiosis, vol. 30, no. 4, pp. 317-328, 2001. 

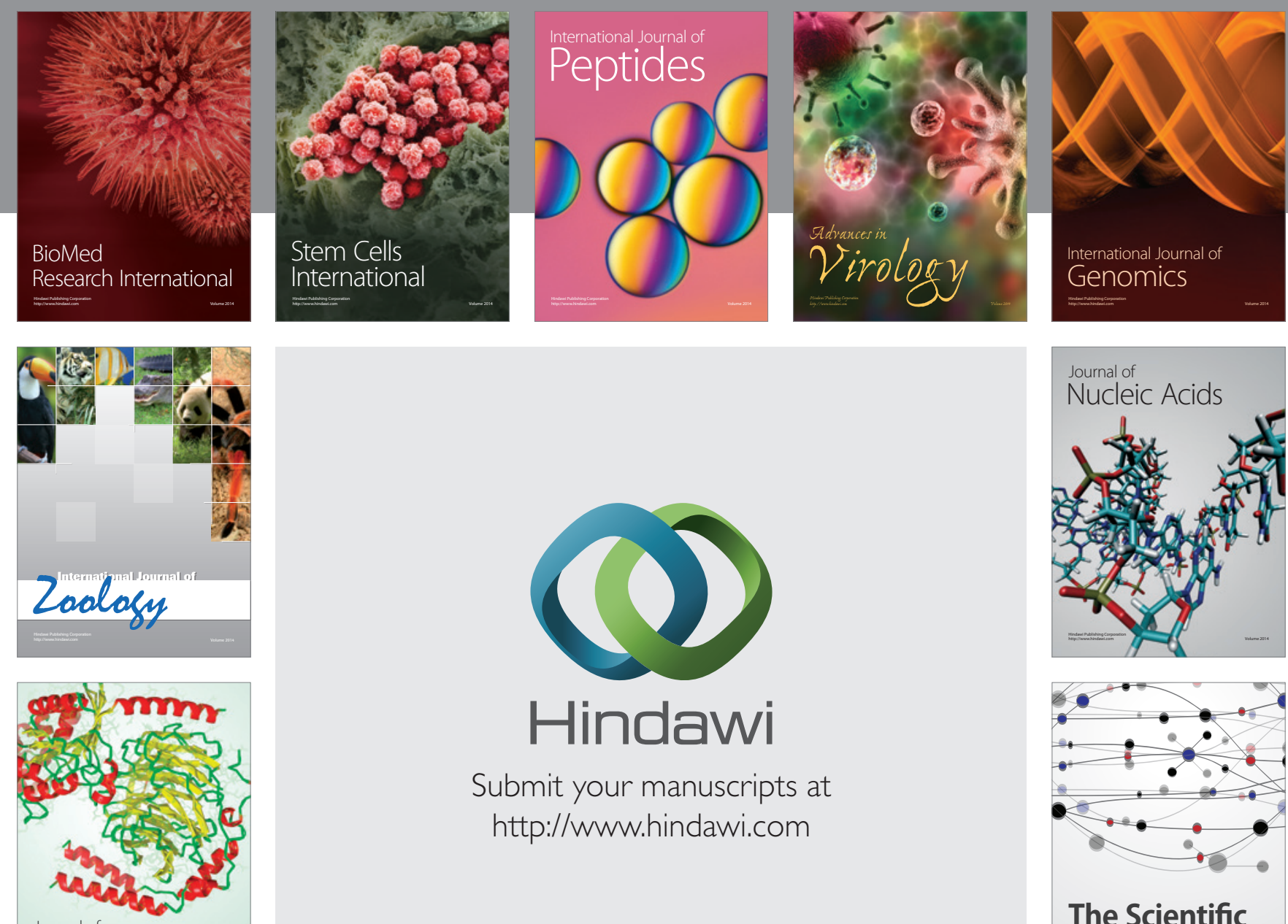

Submit your manuscripts at

http://www.hindawi.com

Journal of
Signal Transduction
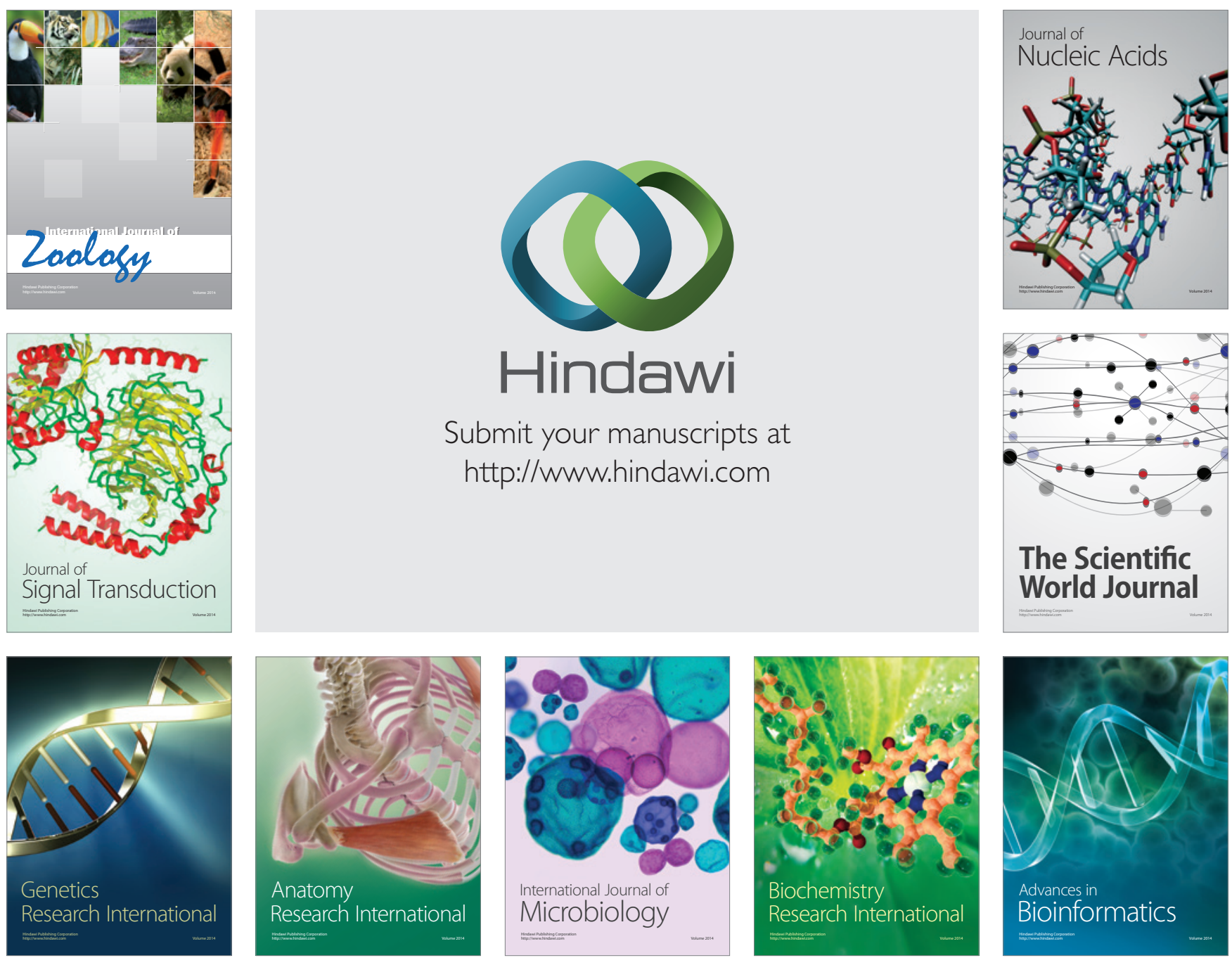

The Scientific World Journal
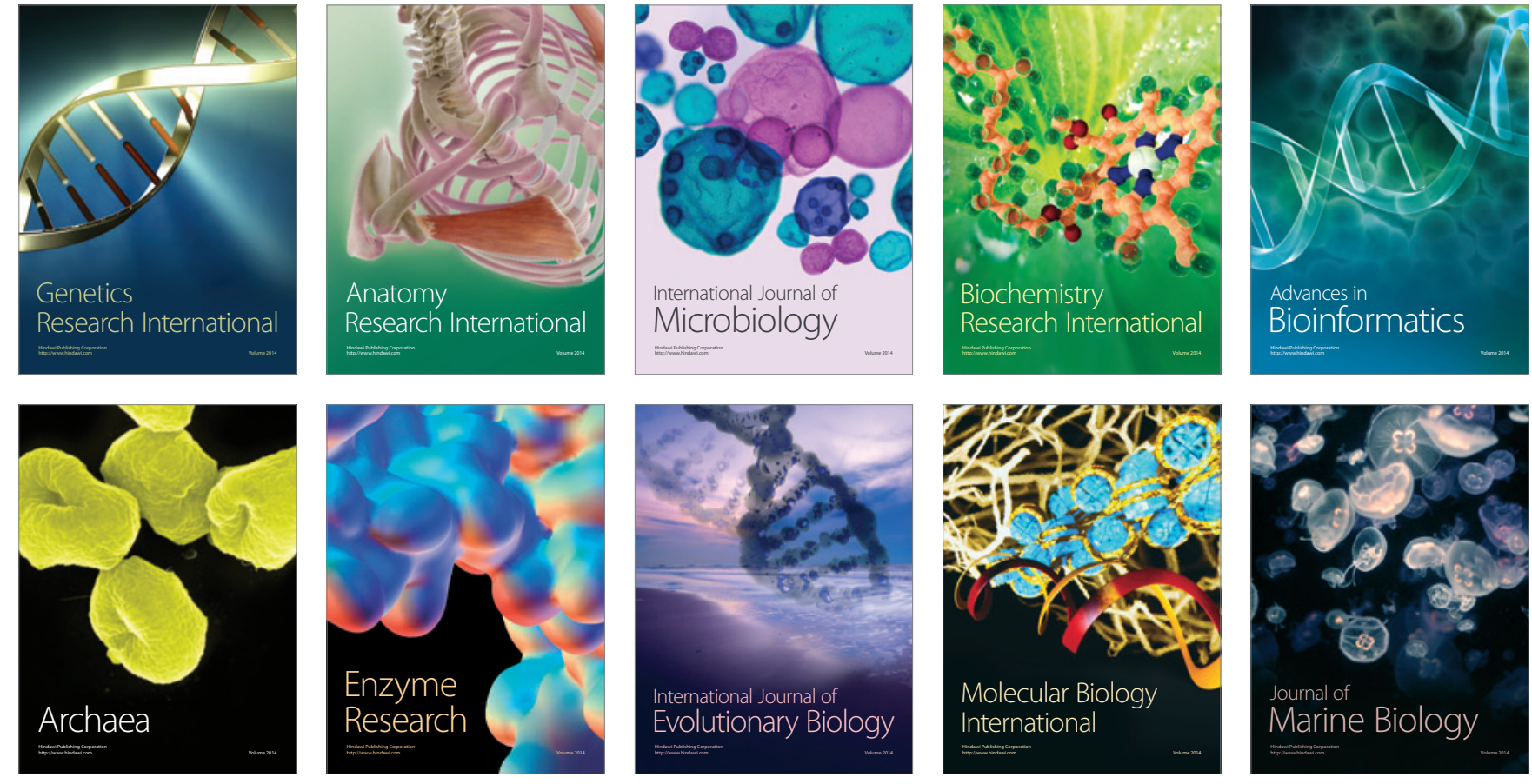